\title{
Financial Sustainability of Selected MFIs of Nepal
}

\section{Puspa Raj Sharma}

This paper aims to analyze the financial sustainability of selected MFIs. In this regard, it deals with concept of sustainability, financial sustainability including operational and financial selfsufficiency. It also deals operating performance, staff productivity, portfolio quality and relation of financial sustainability with other variables. Nepalese MFIs are not strong from status of sustainability perspective at present. PI-MFIs are in better position than GI-MFIs. The data had collected from a special survey carried out in hill and terai in 2004-2006 of Nepal.

Key Words : Sustaiinability, financial, operating, MFIs.

\section{Introduction -Sustainability of MFIs}

Different people perceive sustainability in different ways, and it is difficult to arrive at a consensus on this issue. Organizations that are committed to earning profit only consider financial sustainability, without taking about institutional, social and environmental issues. On the other hand, organizations that are involved with the development attach a higher value to sustainability. A recent publication defined "the sustainability as development that meets the need of the present without compromising the ability of future generations to meet their own needs (Schrieder, 2000: 5)". In general view, sustainability is considered as development, which is about bringing certain types of positive changes in a dynamic system, linking ecology, economy and society.

According to Robert Gilman (1990) "Sustainability refers to the ability of a society ecosystem or any such ongoing system to continue functioning into the indefinite future without being forced into decline through exhaustion... of key resources."

CGAP (2003) states that sustainable means repeatable. Sustainability has two facets: the sustainability of a transaction and the sustainability of an organization. Sustainable transactions are repeatable. Sustainable organizations have the structure and incentives to repeat transactions. Micro-finance sustainability means an MFO is sustainable and keeps its mission for the poor. Micro-finance self-sustainability means an MFO is micro-finance sustainable without help from donors. Micro-finance self-sustainability implies an MFO is worthwhile from now on from the point of view of society, but micro-finance sustainability does not necessarily imply anything about performance from the point of view of society.

Mayoux (1999) states that "Performance is meeting goals. Sustainability is meeting 
goals now and in the long term. An MFO has six groups of stakeholders: society, the poor, poor customers, donors, workers, and investors. Each group constrains the rest. Each group has its own goals and thus it's own measures of performance. For society, a good MFO makes more social benefits than social costs. For the poor, a good MFO is the best use of the funds in the budget earmarked to help the poor. It costs more to measure benefits than to measure costs. Cost-effectiveness analysis can help to judge whether unmeasured benefits could exceed measured costs. For poor customers, a good MFO gets repeated use. For donors, a good MFO uses public funds to attract market funds. For the workers of an MFO, a good MFO means a good job. Such an MFO would not shrink if donors withdrew support. For investors, good performance means a market return."

Hollis and Sweetmen (1998) expressed that sustainability is one of the major issue in micro-finance. The most striking emerging point is that depositor based MFI tend to last longer and serve many more borrower than MFI financed by donations or government. A good institution can be successful in attracting local depositors who in turn serve to protect the health of the organization.

Hulme \& Mosley (1996) explained that the issues of sustainability in micro-finance have interrelated and complementary dimensions. They explain that the three interrelated sustainability issues in Micro-finance are: MFI's borrower sustainability, MFI's financial and economic viability, and macroeconomic stability

Ahemed (2001) have suggested some indicators of financial sustainability ratio, operating efficiency ratios and portfolio quality ratio.

\section{Methodology and Data}

The study is mainly focused on financial sustainability of MFIs. For this, basically a descriptive cross sectional analytical research design was adopted. As a frame of reference, various scattered research works were used which helped to analyze and interpret the qualitative and quantitative data. For the purpose of primary data collection a structured questionnaire survey was done. Besides this, focused group discussion with credit gr oup of MFIs and in-depth interviews with chief of MFIs were conducted. In the process of the study observation and field visits were done in various MFIs of Nepal, Bangladesh's MFIs.

The sampling process has been used on a phase-wise basis to meet the objectives of the study. First of all, the MFIs, were selected which have, adopted Grameen Model and running at least four years of operation from private and public sectors. After that four largest MFIs were selected from the total number of nine MFIs in Nepal. Two largest from privately initiated (PI) institutions i.e. NUB, SBB and two largest MFIs from government 
initiated (GI) institutions i.e. WGBB and CGBB were taken.

\section{Financial Sustainability and Analysis}

Sustainability requires that MFIs must cover all transaction costs (loan losses, financial cost and administrative cost etc.) with return on equity (net of any subsidy received), and consequently function without subsides. It is the ability of an MFI to maintain or increase its flows of benefits or service through internally generated income or funds. Factors effecting financial viability and sustainability are: outreach, rate of interest, loan size, operational efficiency, clients dropout, operating cost, repayment rate, saving mobilization, management system, financial management skill and institutional capacity (Shrestha, 2001). Most of the MFIs have been experiencing difficulties on attaining sustainability over the long run due to limited outreach and poor financial management (Dhakal, 2001). In this context, financial sustainability of MFIs have been assessed using some of the financial sustainability indicators, such as financial performance, operating performance, operating and financial self-sufficiency ratio, portfolio quality ratio, administrative efficiency and staff productivity of the leading MFIs.

Various financial and operational performance indicators are used to analyze the extent to which MFIs are making the best use of resources and providing services at the least cost. Typical financial and operational performance indicators are financial performance ratios, operational performance ratios and portfolio quality ratios.

\subsection{Financial Performance}

Financial performance measures MFI's ability to attain operating and financial self-sufficiency. The analysis of financial performance includes income analysis, expenses analysis and self-sufficiency analysis.

\subsubsection{Income Analysis}

Interest is the primary income of the MFIs. Income reflects the productivity of the MFI in mobilizing the available resources. Performing asset has special significance for MFI operation, which relates to those assets that have been used for generating income by MFIs. Given that performing asset is the stock concept and income is a flow concept, an estimate on the average performing asset (APA) is required to make them comparable and make the assessment possible. APA can be calculated taking sum of cash and bank deposits, investments and performing portfolio of two accounting periods and divided by two obtained average figures. 
Table 1 : Income Analysis of GI-MFIs and PI-MFIs

\begin{tabular}{|c|c|c|c|c|c|c|c|}
\hline \multirow[t]{2}{*}{ Particulars } & \multicolumn{3}{|c|}{ GI-MFI } & \multicolumn{3}{|c|}{ PI-MFI } & \multirow{2}{*}{$\begin{array}{l}\text { Pooled } \\
\text { Average } \\
\text { of MFIs }\end{array}$} \\
\hline & CGBB & WGBB & $\begin{array}{l}\text { Avg. } \\
\text { Total }\end{array}$ & NUB & SBB & $\begin{array}{l}\text { Avg. } \\
\text { Total }\end{array}$ & \\
\hline \multicolumn{8}{|l|}{ Income Analysis } \\
\hline APA(RS’000) & 425196 & 588572 & 506854 & 415868 & 277045 & 346457 & 426655 \\
\hline Return on APA (\%) & 11.88 & 11.73 & 11.80 & 12.5 & 15.6 & 14.05 & 12.93 \\
\hline \multicolumn{8}{|l|}{ Expenses Analysis } \\
\hline Financial cost ratio( $(\%)$ & 5.48 & 4.76 & 5.13 & 4.4 & 3.8 & 4.14 & 4.64 \\
\hline Administrative cost ratio & 7.28 & 6.48 & 6.88 & 9.7 & 9.30 & 9.49 & 8.19 \\
\hline Loan loss ratio(\%) & 0.91 & .94 & 0.93 & 1.1 & 1.01 & 1.1 & 1.015 \\
\hline Imputed cost of capital ratio & 0.77 & .52 & .65 & 0.34 & 0.93 & .64 & 0.645 \\
\hline \multicolumn{8}{|l|}{ Self Sufficiency Analysis } \\
\hline Operational self sufficiency $(\%)$ & 89.93 & 104.39 & 97.16 & 94.9 & 115.3 & 105.07 & 101.11 \\
\hline Financial self -sufficiency (\%) & 85.01 & 99.66 & 92.34 & 93.7 & 113.3 & 103.51 & 97.93 \\
\hline
\end{tabular}

Average performing assets (considering last five years) of selected GI- MFIs and PIMFIs are Rs. 506.85 million, and Rs. 346.46 million. It shows performing assets of GI-MFIs are more than the PI-MFIs. Out of the four MFIs, WGBB has the highest average performing assets of Rs.588.51 million and SBB has the lowest APA of Rs.277.04 million.

As stated earlier, interest income from mobilizing performing asset is the main income of MFIs. Total income to average performing assets is an indicator of financial productivity of credit services. An increasing return on APA is a positive signal. Analysis of this ratio is useful for determining the impact of lending policy changes that might affect loan return and commissions. Total income to APA of PI-MFIs is greater than the GI-MFIs. On an average, GI-MFIs has 11.80 percent return, whereas PI-MFIs has 14.05 percent return. The average of all the MFIs is 12.93 percent. It shows that the total income to APA is lower than the interest rate charged by these institutions.

\subsubsection{Expenses Analysis}

Expenses of an MFI can be grouped into interest costs, operating costs, risk costs and imputed costs of capital.

\section{Interest Costs Analysis}

Interest costs relate to the costs of the borrowed fund i.e. external loans and savings of the clients. Interest cost ratio shows average cost of funding organization's assets with debts.. 
The interest cost of sample MFIs range between 3.80 percent to 5.48 percent. The financial cost of PI-MFI (4.14 percent) is lower than GI-MFI (5.48 percent). This indicates a relative imperfection and inefficiency on accessing loanable fund by MFIs from the financial market. The reason is that the cost of funding of MFIs is substantially lower than in the open market.

\section{Operating Costs Ratio}

Operating costs relate to the costs of financial inter-mediation i.e. handling the mobilization of the APA used for generating income. Operating cost ratios among the MFIs studied range between 6.40 (WGBB) percent to 9.70 percent (NUB) with an overall average of 8.19 percent. Comparatively WGBB has the lowest ratio as it has made manipulated in the service that they have engaged in larger collateral based loans in urban areas that have contributed to manage activities more effectively than the others. In general Nepalese MFIs (8.19 percent) costs tend to be high due to the social preparation and frequent supervision and follow-up requirements.

\section{Risk Ratio}

MFIs are exposed to the risk that the entire amount disbursed among their clients may not be recovered and may be in the state of risk of loss of the asset.. The ratio indicates provisioning requirements on the loan portfolio for the current period. If standard reserve practices are followed, a decreasing trend on this ratio is a positive development. Regarding the risk ratio, GI-MFI has 0.93 percent as compared to PI-MFI (1.10 percent). On an average the aggregate rate for the selected MFIs seems to be only to be 1.01 percent. It shows that the risk is low and their clients are meeting norms of repayment.

\section{Imputed Cost of Capital Ratio}

All the assets used by MFI on micro lending are not priced at full cost. In general, all the liabilities are priced and that the net worth (share capital, retained earnings and reserve) is considered free and is not priced. The imputed cost ratio ranges between 0.34 to 0.93 and overall average imputed cost is 0.645 . PI-MFIs $(0.64)$ are slightly in better position than the GI- MFI (0.65).

\subsection{Self-sufficiency Analysis}

Self-sufficiency relates to the MFI's ability to run its own by using its own programs by income in the future. In this study, MFIs operating self-sufficiency and financial selfsufficiency have been analyzed. 


\section{Operating Self- Sufficiency Ratio}

Operating self-sufficiency relates to the MFI's ability to meet the operating costs from their income. The operating self -sufficiency ratio is defined as the financial income divided by sum of financial costs, operating costs and loan loss provision. The OSS indicates whether enough revenue is earned to cover organization's cost. An increasing trend in OSS of MFIs ranged between 90 percent to 115 percent of which overall average of 101.76 percent. But one fact that emerges conclusively that PI-MFI (105 percent) is in a better position than the GI-MFIs (97 percent).

\section{Financial Self- Sufficiency (FSS) Ratio}

Financial self-sufficiency (FSS) relates to the MFI's ability to meet all the financial costs including inflation to maintain value of the asset due to inflation from their income. Except SBB (113 percent) other MFIs are not near a position of financial self-sufficiency. While comparing between PI-MFI and GI-MFI, the first group MFIs (103 percent) are in a better position than the latter (92 percent). Especially CGBB (85.01 percent) position falls on poor status than the other three MFIs.

The level of financial self-sufficiency in GI-MFIs and PI-MFIs was also tested by using Mann Whitney U-Test. The result also shows the difference in financial self-sufficiency level in two categories of MFIs, which is statistically also significant. The calculated value of $\mathrm{Z}$ is 2 , which is greater than its table value 1.96 at 5 percent level.

\section{Operating Performance}

Sustainability of MFIs essentially depends on their operating efficiency in the given environment. For sustainability, they need to minimize transaction costs, especially administrative expenses. Operating performance relates to MFIs' ability to maintain their non-financial cost at a reasonable level. Some indicators for operating performance are ratios, such as salary cost to APA, loan per motivator, gross loan portfolio to total staff ratio.

\section{Table 2 : Operating Performance of MFIs}

\begin{tabular}{|c|c|c|c|c|c|c|c|}
\hline \multirow[b]{2}{*}{$\underline{\text { Particulars }}$} & \multicolumn{3}{|c|}{ GI-MFI } & \multicolumn{3}{|c|}{ PI-MFI } & \multirow{2}{*}{$\begin{array}{l}\text { Pooled } \\
\text { Average } \\
\text { of MFIs }\end{array}$} \\
\hline & MGBB & WGBB & Total & NUB & SBB & Total & \\
\hline $\begin{array}{l}\text { 1. Administration cost / } \\
\text { Transaction cost }(\%)\end{array}$ & 52 & 46.1 & 49.1 & 55.2 & 76.9 & 66.04 & 57.57 \\
\hline $\begin{array}{l}\text { 2.Personnel cost / } \\
\text { Administration cost }\end{array}$ & 78 & 69.5 & 73.6 & 41 & 35.2 & 38.09 & 55.85 \\
\hline $\begin{array}{l}\text { 3. Administration cost } \\
\text { to APA }(\%)\end{array}$ & 8.09 & 5.51 & 6.79 & 8.09 & 8.5 & 829 & 7.50 \\
\hline
\end{tabular}




\subsection{Administrative Cost to Transactions Cost Ratio:}

This ratio is simple division of administrative costs by total transaction costs. It indicates transaction efficiency of MFI. According to Christesen (1997), the norms of "optimal practices" assume that well-managed MFIs should able to maintain the ratio of administrative cost to total transaction costs around 15 percent to 25 percent. GI-MFI ratio is 49.10 percent and PI-MFI ratio is 66.04 percent, which shows overall 57.57 percent. Administrative costs to transactions a cost ratio in Nepal is found to be very high compared to international standard.

\subsection{Administrative Costs of APA}

It shows the relation of administrative costs to average performing assets of MFIs. This ratio indicates rupees that MFI spend for managing Rs 100 under their operation.. In a true sense, overall viability of MFIs depends to the extent at which can operate at low cost level. This administrative cost ratio ranges between 5.51 percent to 8.90 percent overall average of 7.54 percent.

\subsection{Personnel Costs to Administrative Costs}

The personnel costs to administrative costs give the picture of share of the personnel cost to total administrative costs. This ratio ranges between 35 percent 78 percent and overall average of 55.85 percent. CGBB has the highest ratio and SBB has the lowest personnel costs to administrative ratio.

\section{Staff Efficiency}

As mentioned earlier, personnel cost is one of the important components of administrative cost in micro- finance operation. It ranges between 56 percent and 70 percent of total amount of administrative expenses. The details of indicators explaining the staff efficiency are presented below:

\section{Table 3 : Staff Efficiency of MFIs}

\begin{tabular}{|l|r|r|r|r|r|r|r|}
\hline \multirow{2}{*}{\begin{tabular}{l} 
Particulars \\
\cline { 2 - 8 }
\end{tabular}} & \multicolumn{3}{|c|}{ GI-MFI } & \multicolumn{3}{|c|}{ PI-MFI } & $\begin{array}{c}\text { Pooled } \\
\text { average } \\
\text { of MFIs }\end{array}$ \\
\hline 1. Member per staff(no) & 142 & 169 & 157 & 189 & 264 & 227 & 192 \\
\hline 2. Loan clients per staff(no) & 137 & 163 & 150 & 151 & 212 & 182 & 166 \\
\hline 3. Loan clients to total mem- & 96 & 96 & 96.31 & 80 & 80.37 & 80.18 & 88.09 \\
\hline ber (\%) & 5 & 3.59 & 4.3 & 4.6 & 5.1 & 4.85 & 4.58 \\
\hline 4. Salary cost to APA (\%) & & & & & Notal \\
\hline
\end{tabular}


Financial Sustainability of Selected MFIs of Nepal

\begin{tabular}{|c|c|c|c|c|c|c|c|}
\hline$\frac{5 \text { Outstanding loan portfolio }}{\text { per staff (Rs. '000) }}$ & 912 & 1437 & 1174 & 7375 & 6911 & 7143 & 1231.4 \\
\hline $\begin{array}{l}\text { 6. Average outstanding loan } \\
\text { per member(Rs.) }\end{array}$ & 6633 & 8794 & 7713.5 & 7375 & 6911 & 7143 & 7428.2 \\
\hline
\end{tabular}

\subsection{Active Member per- Staff}

Staff productivity is one of the indicators of operating efficiency. Normally credit officers/motivators are the main productive workers in the MFI operation. They are crucial staff in MFIs and their future depends upon their performance. Active clients per staff ratio give an indication of working efficiency of the staff. The ratio per staff ranges between 142 (CGBB) to 264 (SBB) and the overall average of all MFI is 192. In this matter PI-MFI (227) are in a better position than the GI-MFIs (157). Compared with Bangladesh (307) it reveals substantially lower in terms of active member per staff. It shows that Nepalese MFIs may have to go a long way to be truly sustainable.

\subsection{Loan Client Per Staff Ratio}

Loan clients are the most valuable agents in MFI operation. Income of MFI depends on loan clients' willingness to receive financial services on continuous basis. For efficiency MFI requires that their entire client borrow and make disciplined transaction. In above table per staff loan client ranges between 137 (CGBB) to 212 (SBB) with an overall average of 166. In this aspect also PI-MFIs (182) is in a better position than GI-MFIs (150). Comparing to Bangladesh (276) it shows substantially lower in terms of loan clients per staff.

\subsection{Loan Client to Total Member Ratio}

Loan client to total member ratio gives an indication on the proportion of borrowing clients among the total clients of the MFI. It has a special significance in MFIs operation. The loan clients to total clients' ratio fluctuate on an in average of 80 percent to 96 percent. In this aspect GI-MFIs (96.13) are in a better position than PI-MFIs (80.18). Comparing to Bangladesh (83.13 percent) loan clients to total member ratio was encouraging.

\subsection{Salary Cost of APA}

Salary cost incurred by the MFIs for handling per unit of APA is very important for viability of MFI. Salary costs to APA ratio is calculated by dividing salary costs by APA. This ratio ranges between 3.60 percent to 5.10 percent with average of 4.58 percent. In this aspect GI-MFIs (4.6 percent) are in better position than the PI-MFIs ( 4.85 percent). 


\subsection{Outstanding Portfolio per- Staff}

Outstanding loan is the single most important earning asset of the MFI and outstanding loan portfolio managed by the staff determines their contribution on MFIs' income. This ratio is defined as the total outstanding portfolio divided by the total number of staff. The portfolio is ranged between Rs. 912 thousands to Rs. 1459 thousands with average of Rs. 1231.4 thousand. One noticeable aspect is that privately initiated MFI has average of Rs 1289 thousand outstanding loan portfolio in comparison to government initiated MFI of Rs. 1174 thousand. Comparing to Bangladesh 1378 thousand taka (equivalent to Rs 1860 thousand) outstanding portfolio per staff is lower. It indicates that financial sustainability can be achieved through increased outstanding portfolio per staff.

\subsection{Average Outstanding Loan Per Member}

This ratio is simply defined as total outstanding loan divided by total loan clients. Per loan clients size of loan ranged between Rs. 6633 to Rs. 8794 with an overall average of Rs.7428.25 It shows that MFIs are focusing their investment on micro lending. GI-MFIs have an average of Rs. 7713 in comparison to PI-MFIs Rs.7143. It shows private MFIs have focused on a smaller loan size per member. Compared to Bangladesh (4993 taka) it shows higher average loan size.

\section{Portfolio Quality}

MFIs are essentially credit-driven. Loan portfolio needs to be managed well. Unrecovered loans may become biggest liability of MFIs. Good portfolio management is basic necessity feature of a sustainable institution. Bad portfolio quality saps energy of an institution as staff attention has to be diverted to loan recovery that lead to the cost escalation with additional effort, while income begins to fall as a result of missed interest payments. In order to supply their services on a sustainable basis, it is imperative that MFIs maintain high repayment rates. Failing to maintain quality of their loan portfolio can affect their efficiency. In this study most of the MFIs have less than 2 percent in arrears strata. Commonly used portfolio quality indicators are portfolios in arrears ratio, portfolio at risk ratio and loan loss ratio.

\subsection{Portfolio in Arrears Ratio}

Arrears portfolio relates to the amount of portfolio not recovered in time. Portfolio in arrears is defined as payments in arrears divided by outstanding loan balance. As such, it indicates proportion loan payment past due. It considers only those payments of a loan that are currently past due. A decreasing trend is positive signal and increasing trend is negative 32 
signal. Most of the MFIs are reporting their arrears ratio at less than 2 percent. It shows positive and satisfactory loan portfolio in selected MFIs so far.

\subsection{Loan Loss Reserve Ratio}

MFIs are always exposed to the risk that the entire amount disbursed among their clients may not be recovered and are in a state of the risk of loss. In order to cope with such likely situation, MFIs set aside part of their financial income as loan loss provision to be used to cover likely loan loss risks. Loan loss reserve ratio ranges from 0.1 percent to 1.22 percent with an average of 0.85 percent.

\section{Conclusions and Recommendations}

Nepalese MFIs are not strong from status of sustainability perspective at present. PIMFIs are in better position than GI-MFIs. Of the four selected MFIs, NUB, SBB, WGBB have prospects for attaining viability and self-sustainability, while the same for CGBB is weak and doubtful. The overall causes of weak situation are : lack of national micro-finance policy, lack of apex regulatory body, lack of micro-finance culture on the part of MFIs, lack of commitment of MFIs to serve the poor, obsession of MFIs with sustainability equation, over-emphasis of MFIs on the expansion of number of clients, extension of repeat loans, and maintaining repayment schedule, low financial performance of GI- MFIs, fund parking of wholesale lending institutions, fixation of micro-finance loan ceiling by NRB, lack of dynamism and institutional development of micro-finance groups, lack of office building, and confinement of group activities to gatherings for borrowing and servicing of debt, lack of motivated and committed leadership in GI-MFIs, high staffing prior to the operation of the GI- MFIs (CGBB), low productivity of the staff in comparison to Bangladesh, and instability in the country

Despite a number of problems, institutional commitment and leadership are essential from the board of directors to the field staff providing services to the clients. In Bangladesh, the visionary leaders of the country's principal MFIs have been powerful force for the development of the industry internationally, as well as for the strength and vibrancy of the sector in that country (World Bank, 2005:p 122). The design of target group oriented financial system must always be such that the cost incurred in delivering the services can be met with the income they generate (Hulme, 1996) Even self -sustainable institution however, can not raise prices unilaterally because effective demand may disappear (Krahenen and Schmidt, 1994). Standardized services allow less expensive, decentralized decision making and accountability (Rhyne and Otero, 1993). 
Empirical studies show the most transformed MFIs (NGO to micro-finance development banks) have achieved encouraging results (Hulme \& Moseley, 1996). The present study also matches with the view that recently transformed NGO(CSD and NIRDHAN) into MFIs (SBB and NUB) shows better results. It also points out government run MFIs can not be run efficiently and effectively due to various barriers as noted public enterprises. It should operate as a business unit and attain self-sufficiency. There has been extensive debate about self-sufficiency (named also cost recovery/institutionalist) and subsidized or welfare approach of MFIs. Both approaches have its strong arguments. First approach emphasis on financial self-sufficiency and institutional scale of MFIs whereas second approach emphasis on direct poverty alleviation among the very poor. MFIs should establish /set norms for i) return on APA, ii) ratio of financial cost and operating cost to APA, number of loan to motivators, outstanding portfolio to motivators, motivators to total staff and loan size, and iii) amount of transactions to be carried out at a given level of expenditure for their sustainability. They should monitor and evaluate their status and performance periodically against the establish benchmarks.

Self sufficiency approach is supported by CGAP (2003), World Bank and USAID (2000), CMF (2005), ADB (2000), Otero and Rhyne (1994), Harper (1995), Malhotra (1997) and second approach is supported by Welfariest Christen (1997), Rodey (1997) and others. The researcher argue that country like ours should follow both subsidized and self-sufficiency. Due to the involvement of social cost in the initial period of MFIs/NGO should be provided subsidy either on time basis or on client basis.

There is a role for donor financial assistance in expanding the capital base in emerging micro-finance institutions as well as in developing technical capacity that leads to organizational sustainability. Hence, subsidies can be justified to support 'infant' microfinance institutions as long as there is a viable route to institutional sustainability. The duration of these subsidies would vary according to local conditions and level of poverty of the clients. In the name of financial self sufficiency, if we are not cooperating infant MFIs, they can not recover the initial social cost, which ultimately can not address their services to the poor. So the role of donors should be worked as a complement rather than a competitor for the private MFIs. After crossing a certain phase, MFIs must sustain by themselves by increasing theirs outreach and economies of scale. 


\section{References}

Agrawal, Govind Ram (2003). "Critical Issues and Poverty Reduction through Rural Credit in Nepal”. Agriculture Credit Vol.30

Agrawal, Govind Ram (2005)."Rural Entrepreneurship and Agricultural Development Bank". Agriculture Credit Vol.38.

Ahmed, M. (2002). Key to Achieving Sustainability. ASA’s Publication : Dhaka, Bangladesh

Asian Development Bank (2002). Finance for the Poor. Vol.3 No. 2 Manila:ADB/M

Asian Development Bank (2002). Poverty Reduction in Nepal: Issues, Findings and Approaches. Manila: $\mathrm{ADB} / \mathrm{M}$, March

Asian Development Bank (2003). Finance for the poor: Microfinance Development Strategy Manila: ADB/ $\mathrm{M}$

Asian Development Bank (2005). The Role of Central Banks in Micro-finance in Asia and the Pacific. Vol.1, Overview Manila: ADB/M.

Bajracharya, P. (2003b). Micro and Small Enterprises - An Integrated and Project Report on Policy Review. MEDEP/UNDP.

Bajracharya, P. and Bajaracharya S. (2005). "Total Factor Productivity Growth in Nepal -An Estimate". Agriculture Credit Vol.38.

Carney, D. (1992) Sustainable Rural Livelihoods, What Contributions can we Make? DFID : London.

CGAP (2001). Micro and Small Enterprises Finance Guiding Principles Supporting Intermediaries, CGAP, World Bank, Washington D.C.

CGAP (2003). Anatomy of Micro-finance Deal: A New Approach to Investing in Micro-finance Institutions Focus Note, World Bank, Washington D.C

Christensen, G (1993). The Limits of Informal Financial Intermediation. World Development, vol. 21, no. 5, pp. 721-731.

Christen, R. (1997) Banking Service for the Poor, Managing for Financial Success. Accion : Cambridge (USA).

Dhakal, N. H. (2004). "Micro-finance for achieving Millennium Development Goals in Nepal”. Agriculture Credit Vol.37 Jan.

Harper, M. (2003) Micro Finance Evaluation, Achievement and Challanges, Sanskriti : New Delhi.

Hossain, M.(2002). Credit for the Rural Poor, the Experience of Grameen Bank in Bangladesh, Research Report, IFPRI and BIDS, Washington D.C.

Hulme D.\& P. Mosley (1996). Finance against Poverty. Volume I\&II Routledge, London.

Khandker S.R.(2003). "Micro-finance and poverty: evidence using panel data from Bangladesh". World Development Vol.31 no. 3 pp.647-665

Kidder T. (1997 ). "Macro Debates at the Micro-Credit Summit". Development in Practice, Vol.7,No.4, pp432-439.

Ledgerwood, Joanna (1995). Philippines Poverty Strategy Report: Access to Credit for the Poor. Washington D.C.: World Bank, East Asia Country Department.

Ledgerwood, J (1997). Critical Issues in Nepalese Micro-finance Circumstances IRIS Center, Maryland. March

Mayoux, L (1999). Women's Empowerment and Microfinance Programs : Approaches, Evidence and ways for ward. DDP Working Paper No. 41.

Morduch, Jonathan, (1999b).”The Micro-finance Promise”. Journal of Economic Literature, XXXVII (4): $1569-1614$.

Ostergaard L.(1992). Gender and Development :A Practical Guide. Routledge, London.

Rhyne, Elissabeth and Maria Otero (1994). A Financial System Approach to Micro-enterprises GEMINI Working Paper 18, Washington D.C.

Robert, Gilman (1990) “The Informal Financial Sector in Bangladesh: An Appraisal of its Role in Development”. Development and Change 23:147-68

Robinson, M.S.(1996). “Addressing Some Key Questions on Finance and Poverty”. Journal of International Development 8(2):153-61

Schmidt, Reinhard H. and Claus-Peter Zeitinger(1996). "Prospects, Problems and Potential of Credit Granting NGOs". Journal of International Development, 8(2): 241-58. 
Schuurman F.J. (1993) Beyond the Impasse: New Directions in Development Theory. Zed. Books London.

Schriners, S. (2003) "Sustainrable Rural Livelihood" DFID : London.

Sharma, Puspa Raj (2003) "Micro-finance Programs and Delinquency Management in Nepal” Comment Paper on the Paper presented in a Seminar Organized by SAP-Nepal, Pokhara, Dec.12

Sharma, Puspa Raj (2004). "Entrepreneurship Competency Development program : A Case study of Pokhara Sub-Metropolitan City". The Journal of Business and Management, Vol 2.No.1, January Pokhara University

Sharma, Puspa Raj (2004). "Micro-finance Programs and its Sustainability in Nepal " Paper presented in a Seminar organised by SAP-Nepal, Pokhara, July 5

Sharma, Puspa Raj (2004). "Micro-finance: A powerful Tool for Social Transformation, its Challenges and Principles'. The Journal of Nepalese Business Studies, Vol 1.No. 1 pp69-74, P.N. Campus, Pokhara.

Sharma, Puspa Raj (2006)."Micro-finance and its Service Development-Challenges and Opportunitiy in Nepal". Banijya Sansar Issue 12, Central Department of Management, TU Nepal.

Sharma, Puspa Raj (2007). "Micro-finance and Women Empowerment". The Journal of Nepalese Business Studies, Vol IV.No. 1 pp16-27, P.N. Campus, Pokhara.

Sharma, Puspa Raj(2003). "Micro-finance Programs and its Strategy to Deliver Services on Poorest of the Poor in Nepal " Paper presented in a Seminar Organized by South Asia Partnership -Nepal, Pokhara , Dec.31

Sharma, Puspa Raj(2004). Millenium Development Goals and International Year of Micro-finance 2005 in the Context of Nepal. The Journal of Nepalese Business Studies, Vol 2.No. 2, P.N. Campus, Pokhara

Sharma, S.R. (2003). "Micro-finance against poverty: The Nepalese Scenario". Economic Review, Occasional Paper, Vol.15, Nepal Rastra Bank, Nepal.

Wolf, Howard K.\& Pant, Prem R.(2002, 3rd edition). A Handbook for Social Science Research and Thesis Writing. Kathmandu: Research Division, Tribhuvan University

World Bank, (2002). World Development Report 2002/2003, Attacking Poverty New York: Oxford University Press

Wright G.A.N.(1999). "Examining the Impact of Micro-finance Services _Increasing Income or Reducing Poverty". Small Enterprise Development, Vol. 10, No 1, pp 39-47.-

Yunus, M. (2002). Grameen Bank II : Designed to Open New Possibilities? Originally published in Grameen Dialogue, Grameen Bank, Mirpur Dhaka, Bangladesh.

Yunus, M. (2003). Halving Poverty By 2015-We can Actually Make It Happen? Grameen Bank, Mirpur Dhaka, Bangladesh

\section{Related Websites for Micro-finance}

www.accion.org

www.adb.org

www.bellannet.org.partners/mfn.

www.calmedow.com

www.cgap.org

www.gdrc.org

www.ice.gov.it

www.microbanking-mbb.org

www.microfinance.com

www.microfinancegateway.org

www.microfinancesummit.org

www.nabard.org

www.nrb.org

www.pactpub.com

www.rmdenepal.com

www.themix.org

www.uncdf.org

www.undp.org

www.usaid.gov

www.worldbank.org/htm/cgap.htm 